\title{
A Study on Irregular Migration from Bangladesh to Malaysia through the Bay of Bengal and the Andaman Sea
}

\author{
Afzalur Rahman*) \\ Department of International Relations, Faculty of Social Sciences, University of Chittagong, \\ Chittagong-4331, Bangladesh.
}

Received: 2 February 2020; Revised: 30 August 2020; Accepted: 15 October 2020

\begin{abstract}
Irregular migration is an issue of great concern for today's world. There are various factors which are responsible for this conundrum. These are overpopulation, natural disaster, poverty, illiteracy, lack of employment opportunities, for a better life etc. Thus, irregular migration has been a livelihood strategy for the millions of people worldwide for the long time. Bangladesh is one of the top countries of the world in terms of sending labor migrants. Every year thousands of Bangladeshis are migrating overseas either legally or by illegal means for a better livelihood. However, in the last couple of years, total remittance flow was not satisfactory because of the diplomatic tension between Bangladesh and major migrants receiving countries. In addition, the new migrations policies of the Middle-Eastern countries which is the main destination points for Bangladeshi migrants in terms of single regions also have shrunk the scope. As a result, the number of irregular migrations from Bangladesh to Malaysia has increased. This paper attempts to unveil the key causes of irregular migration through the risky Bay of Bengal and the Andaman Sea by analysing the field data. It will focus on the case studies of the trafficking victims and their family members with focusing on why they took this dangerous path of irregular migration. It also argues for an effective mechanism to monitor the whole process of irregular migration from Bangladesh to Malaysia on an urgent basis.
\end{abstract}

Keywords: Andaman Sea; Anti-Trafficking Policy; Bay of Bengal; Boat People; Irregular Migration; Trafficking Victim

How to Cite: Rahman, A. (2020). A Study on Irregular Migration from Bangladesh to Malaysia through the Bay of Bengal and the Andaman Sea. Otoritas : Jurnal Ilmu Pemerintahan, 10(2), 120-131.

Permalink/DOI: https://doi.org/10.26618/ojip.v10i2.4640

${ }^{*}$ Corresponding Author.

E-Mail : afzal@cu.ac.bd

Copyright (C) 2020, Otoritas : Jurnal Ilmu Pemerintahan, ISSN: 2088-3706 (Print), ISSN: 2502-9320 (Online) 


\section{INTRODUCTION}

Irregular migration is an issue of great concern for today's world. There are various factors which are responsible for this conundrum. These are overpopulation, natural disaster, poverty, illiteracy, lack of employment opportunities etc. Thus, migration has been a livelihood strategy for the millions of people worldwide for the long time. Bangladesh is one of the top countries of the world in terms of sending labor migrants (Azad, 2019). Moreover, Around more than 12 million Bangladeshis live outside of their country, which comprise $13 \%$ of all population (Hossain, 2020). However, even today poor as well as better-off people pursue migration for changing their living conditions. The choice of destination and level of benefit side by side risk varies from country to country in terms of socioeconomic paradigm. Practically, international migration takes place within the legal framework between the sending and receiving states. The main destination countries for Bangladeshi migrants are Saudi Arabia, UAE, Kuwait, Qatar, Oman, Iraq, Libya, Bahrain, Iran, Malaysia, South Korea, Singapore, Hong Kong and Brunei (Siddiqui, 2003). The traffickers use the Bay of Bengal as a transit route to migrate Malaysia illegally. The fishing season from October to January is the high time for irregular migration (Siddiqui, 2014).

Bangladeshi migrants in Malaysia are allowed to work only in the construction, agriculture and services sector (Muniandy \& Bonatti, 2014). Thus, Local brokers from Bangladesh, pirates from Andaman, collaborators from Thailand and traffickers from Myanmar are involved in this human trafficking and those irregular migrants called as 'Boat People' (Hasan, 2019). Trafficking of the unskilled labour force from Bangladesh to Malaysia through the Bay of Bengal's maritime route is added a new dimension in the trafficking history of the continent of
Asia. It is one of the dangerous routes of human trafficking. According to United Nation High Commissioner for Refugees (UNHCR) more than 25,000 people from Bangladesh and Myanmar crossed the Bay of Bengal to seek their fortune in Malaysia during the first half of 2015 (Rashid \& Ashraf, 2016). Many of the trafficking victims have lost their lives in the boat because of the torture and hazardous condition. Most of the victims are from the nontraditional migrant's prone areas of the country. These are mainly formed low international labour migration producing districts: Jessore, Khulna, Bagerhat, Sirajgunj, Ragpur, Dinajpur, Brahmanbaria, Pabna and Cox's Bazar (Siddiqui, 2014).

This paper is organised into four sections. The introductory section unveils the objective, literature review, research methodology and questions of the research. The second section reviews relevant issues regarding irregular migration. In the third section, individual case studies will be analysed to map out the root causes of irregular migration. The final section concludes with the findings and discusses Bangladesh's anti-trafficking policies and involving actors to tackle irregular migration.

Problem Statement, the Research Questions and Objectives

Human trafficking as the dominant discourse of irregular migration is mainly for two purposes: trafficking for prostitution and trafficking for forced slavery, or indentured labour. Most of the research on human trafficking is based on women and children focusing on prostitution, forced marriage, and children for camel jokey in the Middle East. Literature mainly focuses less on men's human trafficking to exploit labour and sell them to the industry owner (Aronowitz, 2009; Mahdavi, 2011; Siddiqui, 2005; IOM, 2005; Bacon, 2008; Bohl, 2010; Betz, 2009).

This paper's main objective is to find out the causes of irregular migration from 
Available Online at https://journal.unismuh.ac.id/index.php/otoritas

Otoritas : Jurnal Ilmu Pemerintahan, 10 (2), October 2020, 122

Bangladesh to Malaysia through the maritime routes of the Bay of Bengal and the Andaman Sea based on the field data. In line with the objectives, this study has framed the following questions: Why do traffickers choose Malaysia as a destination country through the maritime route of the Bay of Bengal and the Andaman Sea? And what measures need to take for tackling the irregular migration?.

\section{RESEARCH METHODS}

This research paper has followed the mixed method. Secondary sources of reports and publications of various organisations, journals, booklets, newsletters, photographs, and newspaper clippings have been assessed. Secondary data were collected from the organisations; the Bangladesh National Women Lawyers Association (BNWLA), International Organi-

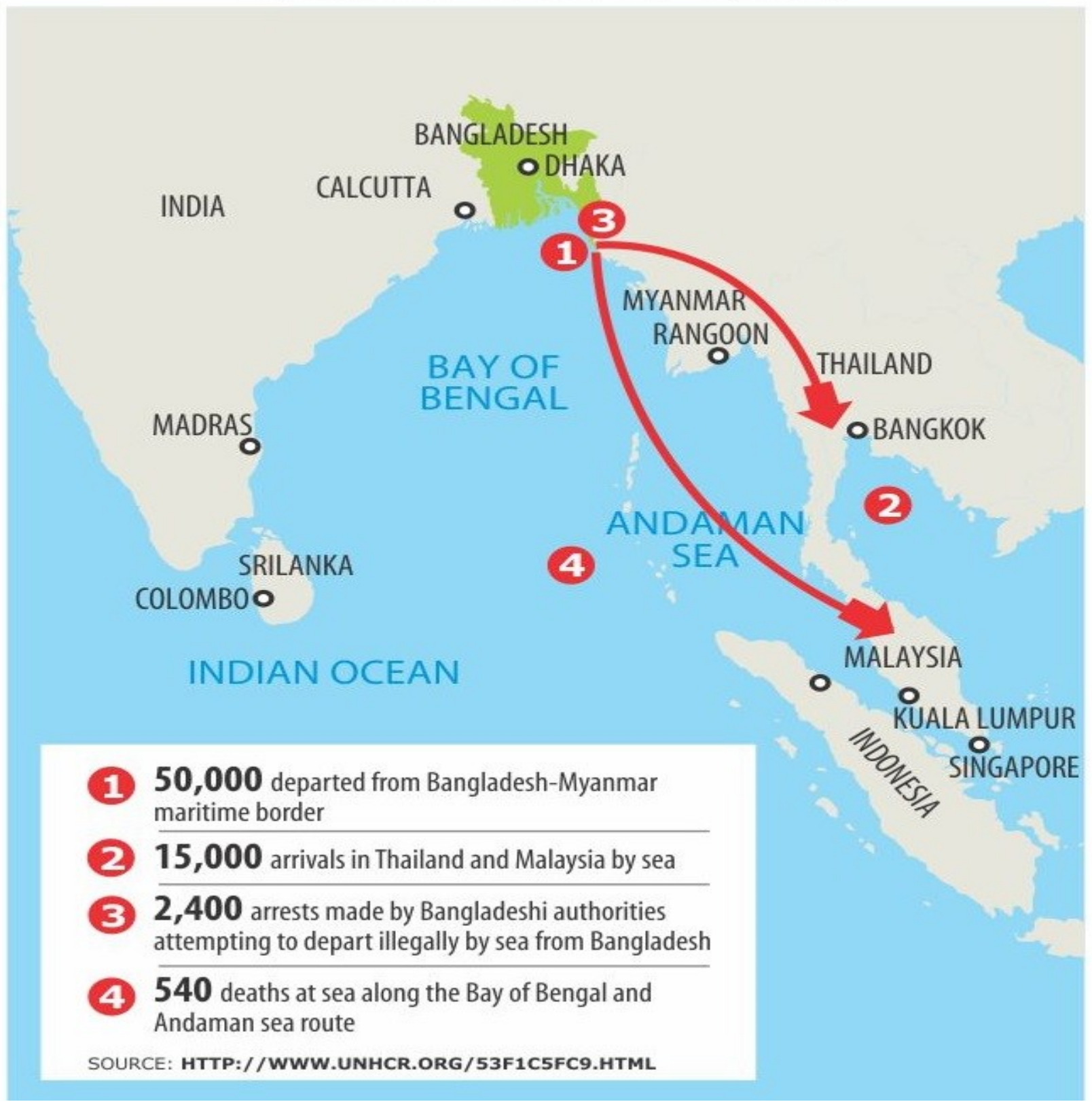

Figure 1. Irregular Maritime Movements from Bay of Bengal Source: UNHCR (2014) 
zation for Migration (IOM), The International Centre for Diarrhea Disease Research, Bangladesh (ICDDR, B,) and Local Government Bodies, Chittagong Metropolitan Police Headquarters' information cell, Refugee and Migratory Movement Unit (RAMMU), Young Power in Social Action (YPSA), Winlock International, International Labor Organization (ILO) through personal visit to their office and from the website.

Interview and case study were followed to collect primary data. The questionnaire covered both open and closeended questions. The sample size of research is 40 that include 20 victims and 20 victim's family members. Due to the hidden nature of the trafficking victims, (Heckathorn, 1997), 30 respondents are taken for interviews where the victims' family members are 23 and 7 . This paper mainly assesses the five individual's case studies. The primary data was collected in 2014 and 2015 from the returnee victims and the family members of the migrants.

\section{CONCEPTUAL AND THEORETICAL ISSUES}

\section{Definition of the Terms}

Irregular migration is a complicated concept. There are lots of ways that a migrant can become irregular migrants. People who enter a country without proper authority called as irregular migrants. It is also the people who have entered a country legally, but after expiring the visa, he/she terms as irregular migrants (Koser, 2007). Human trafficking, smuggling are the two forms of irregular migration. Voluntary and facilitated migrations, exploitation of labour, and prostitution have been included in the definition of human trafficking (Ruhi, 2003). The noticeable difference between the trafficking victim and smuggled persons is that smuggled persons enjoy free movement rights. On the other hand, trafficking victims have to stay in a locked room or firms (Koser, 2007).

Global, Regional and National Perspective

In the global arena, human trafficking and migrants smuggling represent a small portion of the irregular migration. Both of the terms share negative consequences. In 2015 the context of the socalled 'migration crisis' in the Mediterranean Sea, which got huge media attention than migration crisis in the Bay of Bengal and the Andaman Sea (Moretti, 2020).

\section{Regional Context}

Trafficking in Asia is higher than any other region of the world because of the rapid industrialisation and tourism development in South East Asian states. Moreover, the high unemployment rate in the poor Asian countries among potential migrants' easy target of the unauthorised agents (Ullah, 2013) South Asia and Southeast Asia are the vulnerable sources and receiving states of human trafficking. Historical linkage, religious issues, cultural ties, and linguistic similarities play an important component in smuggling, human trafficking, and overall irregular migration.

\section{Bangladesh Perspective}

The causes and impacts of Bangladesh's irregular migration can't be understood without considering the country's socio-economic history and the global community's perception. Current Bangladesh became the part of Pakistan in 1947 which was separated by 1, 200 miles after the partition of the Indian subcontinent by British. During the 1947-1971, many cross-border families were formed between the two parts of Pakistan. Traffickers took the chances of the geographical distance as opportunities. Before the separation of the East-Bengal from West Bengal, Calcutta was the centre of British India. Many Bangladeshis were trafficked to the brothel in Calcutta during that time. It is continuing up to the present days. 
Due to the Gulf Wars in mid-1980s the trends of Bangladeshi migrations shifted from the Middle East to Southeast and East Asian Countries (Ullah, 2013).

United States State Department trafficking in Person (TIP) report 2020 levels Bangladesh as a tier-2 status. However, trafficking is getting an acute condition in Bangladesh. The exact figures of the trafficking victims are very difficult to count.

Major Irregular Migration Routes of Bangladesh

Bangladesh shares the 4,222-km, long border with India and a 288-km border with Myanmar. Twenty-eight out of 64 districts of Bangladesh have the common border with India, and two of the districts have the border with Myanmar. Monitoring and swift initiatives against any unlawful activities in the border area is challenging for both sides' Border Guard. Most of the traffickers used the land border, but a small number of trafficking network use sea routes also. There are 18 transits' points along the Bangladesh-India border through which children and women are smuggled. Beanpole is the common southern spot for trafficking from Bangladesh to India. "The most commonly-used border points for crossing in the north are Hili, Singimari, Mogolhat, Burimari, Durgapur, Villabari, Ramkhana, Vurungamari" (ICDDR'B, 2001). Nowadays, Cox's Bazar has become the new spot for human trafficking to Malaysia via the Bay of Bengal.

\section{RESULTS AND DISCUSSION}

To fulfill the present study's purposes and objective, 30 respondents were selected in a purposive basis from the four Upzila of Cox's Bazar, Rangamati and Chittagong district. In the questionnaire, respondents were asked about the demographic information, causes and measures to curb human trafficking. Five case studies taken from the returnee and the family members of the victim. Those five-case studies state in the following sections.

Case Study 1: Victim's Wife, Age: 32

I saw a middle-aged woman working as a domestic worker in the Khulshi area of Chittagong, whom I selected as a sample for collecting my thesis's primary data. I asked her how many family members in her house. Very simply She replied the details of her family members. She told me the story of her child, who is currently studying in a local school. She managed the tuition fee for her children by working as a domestic worker. She is planning to admit her younger child in a local primary school. She is waiting for better days in the future. She got the offer of a job of 2000 BDT monthly salary for her children in a local shop. She is now 32 years old and served as a domestic worker who is locally known as bhowa. She experienced the tragic moment in her life a few months ago when her husband decided to migrate to Malaysia for a better life. She upset by hearing that her husband finally was ready for going to Malaysia without considering her objection. Her husband older brother managed one lakh BDT for the whole cost of the migration. She didn't know in what ways her husband could go to Malaysia. Local dalals collaborating with the victim's brother had completed all formalities, and he is the Bangladeshi agent to run all the formalities of human trafficking. Shohel is the main dalal in the process of the person's requirement from the different parts of the Nabinagar Uphazilla Bramanbaria of Bangladesh. I asked one question whether she knew about the migration of her husband she said in a regret mode "He didn't say anything to me, only the day when he left the house said goodbye to me, in return I told him, let go foreign country without my consent and you will understand later".

Her husband replied that he did not inform earlier because of her unwillingness to give him support to go aboard. She further said that her husband didn't give any money to lead her livelihood. Later she started to work as a domestic worker 
in various houses of the Khulshi area of the Chittagong. We see the domination of the male in the lower-class family of the Bangladeshi society. Even the migrant family did not know about the 'Human Trafficking and its brutal nature'.

The horrific stories of Amzad Hussein reveal the untold suffering of the victim of trafficking in the Bay of Bengal route to Malaysia. The aftermath of the migration, the migrant family, passed the sorry days in the Chittagong city with her two children. In the first two months, she did not receive any news from her husband. She knew about her husband's news from the newspaper after the Thai police arrest the illegal Bangladeshi migrant from the northern forest of Thailand. She expressed her frustration about the role of the police after the come back of her husband from Malaysia. Police took 15,000 BDT for the bailout of her husband. She stated that her husband is currently unemployed and leads his life in the house dreaming of going aboard again soon. She felt upset again by remembering their family's happy days in a tiny room when her husband works as Periwola in the lane to lane in the city area by earning 250 350 BDT per day income.

\section{Case Study 2: Victim's Father, Age: 58}

I was surprised when Shaising Mong Marma age near around sixty came with my brother's friend in the Chittagong city from Kowakali, Rangamati to search his beloved son. I didn't get any of his points because he spoke in his indigenous language with the Annu Sing Marma, the translator of our conversation. He hasn't received any formal education. Very simply he told me that about five or six months ago his son went to Malaysia through crossing the BangladeshMyanmar border via Bandarban and he crossed the Bay of Bengal to reach Thailand.

After reaching Malaysia, he didn't send any money to the family. Instead he sent around 15,000 BDT to Malaysia for his son. In total the two lakh BDT he cost for his son for the whole migration process. He managed the money by land bandage and barrowing loan from the locals. His son is a married man and left two sons in Bangladesh along with his wife. He is living along with his brother in a joint family. His son influenced by other migrant's family of their locality. His son had to work about 1620 hours as an electrician in Malaysia without any salary. Even these statements of his son in Malaysia could defeat the horrific stories of the slave trade. To escape from these works he left that place and tried to cross the Malaysia and Thailand border and police caught him and sentenced the sixmonth jail. Very recently these police officers of Malaysia demanded 15,000 BDT for the release of his son. They didn't know how to transfer the money from one place to another. It is interesting to notice that the indigenous people of Bangladesh migrate to Malaysia with the broker's false promise to give them a well-paid job in Malaysia. The main difference with other case studies with the son of Shaising Mong is these traffickers' networks are using the new road for the illegal migration through Myanmar with a false identity. There is no difference in terms of colour and race between the indigenous hilly people of Bangladesh and Southeast Asian origin. Thus, it is impossible to separate the indigenous people of Bangladesh from the Southeast Asian people. Traffickers show the case of the neighbours who migrated to Malaysia to convince the victim to go to Malaysia.

Case Study 3: Victim's Father, Age: 55

I went to the bamboo made a halfbroken house of one of the human trafficking victim's houses of Abul Kashem after hearing the stories of the thirteen missing young men from the Jangalkhata Union of khonakali, Chakaria. It is a remote village where most of the inhabitants are farmers. Their profession is based on agriculture. Mr. Kashem cordially gave me the seat in a chair. He looked very depressed and disappointed because 
of his missing son. Nurul Afsar (16) son of Abul Kashem (55) from Badarkhata, Chakaria was left home on July 2013 without discussing with his family members. Before his son's departure, one of the local Chakidars named Muzamel discussed the issue with his father to give him the consent. Muzamel is involved in the human trafficking business. He noted "I have consulted with the many baidos and ojja (one type of medicine) in Bangladesh. Most of them assured me that he is alive and he is passing the very tough time in an uncertain place".

He was speechless during the conversation in his house about his missing son. Afsar influenced by his friend. During the focus group discussion (FGD), I got the information that there is a member of missing individuals in every family of the village. Did his son face any challenges in terms of the monetary issue? I asked the question to the victim's father. "I told my son that please waits for two years. I will arrange the visa of Saudi Arabia and Libya. But my son didn't hear the request." During the conversation, his mother stressed that my son dreams of becoming rich because people don't respect others without money. It is around one and half year he didn't get the news of his very beloved son. My field work's astonishing findings are that at least 13 young men from the same village were missed during Malaysia's journey in traps of human traffickers. They are tired and lost their all of the hope to find their son in the upcoming years. The local member and chairman of the Union Parishad didn't give any visit to the victim's house for getting any news of the victim. How did he manage the money? When I asked this question, he replied that we have spent three lakh BDT for our son after departing the country. These brokers collected the money through hundi. Borrowing the loan, selling the paddy they managed the money. Various brokers' agents from the teknaf took the money in the name of the false promised to give the phone call to his beloved son. At present, he passes challenging days because of debt bondage. People have continuously pressured him for returning their borrowed money. "We are in a very sorry situation; we have lost everything because of our son, it is very unbearable suffering when you lost your son, and it seems that we are dying day by day and we don't show our face to the local because of shame".

Poverty is the main causes to drive his son to migrate to Malaysia. During the post-trafficking period the victim's family didn't get any financial help from the local administration and the non-governmental organisation (NGO). It is very regrettable that local member as well as chairman didn't visit their home. The police administration took the bribe from them in different phases. These poor people are continuously exploited at home and aboard because of their poor condition. Day by day, their daily lives become even worse than ever before because of their beloved son's absence. Their life is even more difficult rather than our imagination. Victim's father was furious to the intermediary's role and he promised to take the revenge of his missing son by attacking the brokers. During our conversation, a young female came with a baby. Kashem introduced her to me that she is the wife of one of the human trafficking victims. He told me that she is begging door to door because of the absence of her husband. At last, during the ending of our interview, he allegedly requests us to do something in terms of monetary help or administrative assistance to normalise their family's everyday life.

\section{Case Study 4: Return Victim, Age: 22}

"I was influenced by one of the fellow namaji (fellows of prayers) of my area who proposed me to give a job in Malaysia without any cost." That was Osman Gani's testimony_after I asked him why he went to Malaysia through the Bay of Ben- 
gal. He is a student of Hasimia Madrasha of Cox's Bazar district. He told me the unbearable sufferings he experienced during the route to Malaysia in January 6, 2014. He and one of his friends from Cox's Bazar government college agreed with the proposal of the brokers because of their high ambition to build up a better life in the future. I asked him to talk about the journey to Malaysia in brief? In January 6, 2014 around 44 passengers from the different localities of the cox's bazar were gathered in a gath of Cox's Bazar in destination to Malaysia. After passing one and half days they reached in the international water of the Bay of Bengal.

He saw a big cargo ship was waiting for them. In that ship, total numbers of passengers were 271, 216 male, 45 female and 10 children. During the journey to Malaysia via the Bay of Bengal they promised him that it would take only one or two days to go to Malaysia. But in the ship, they stayed for 15 days. During these horrific days, at least four or five passengers died due to torture or other reasons. Brokers tortured these passengers. Admittedly, he emphasised that they have no clothes to wear during the trip, and no food to eat and no water to drink in the ship. Only the children of the ship were got regular meals.

"These guard from Burma; Thailand was threat us with the gun and another sharp weapon when we opposed any of their order in the ships". After passing twenty days in the Bay of Bengal's water, they reached in Thailand's jungle. In that place, they passed their life in an inhuman condition. With hiring five cars, the brokers and the guards picked up the human trafficking victims to reach the border of Thailand-Malaysia. At least 20 people were loaded in these cars just like packing of Thailand's fish and other goods. He told about the Thai police identification of them after staying a week in the ThaiMalaysia border. After arrested by the Thai police, he and his friend Arif were fled off from that place destination to Malaysia. After passing three days, they surrendered to Malaysia's border police and told them as Malaysia's citizen. During the police's confession, Osman claimed himself as 17 years old for getting facilities from UNICEF. There was a program for the under 18 undocumented Rohingyas in Malaysia run by the UNICEF. UNICEF's authority sent him to Bangladesh when they identified Osman's identity by receiving 25,000, BDT from the Osman family.

I asked one question to Osman, why did women choose this dangerous path to go Malaysia? According to him, Rohingya women are the main target of the trafficker. There are two primary reasons for the irregular migration of women to Malaysia. One is for the reunion with their husband and second is for the job in Malaysia as a prostitute, the messenger of the beauty parlour. He told about one of the Rohingya married women who went along with them with her three children to meet with her husband in Malaysia. However, during staying in Thailand's jungle, she failed to pay the migration fee because of her guardian refusal. She then decided to flee with one of the Thai traffickers from the ship, and finally, she did. In the end, Osman once again dreams to go foreign country if he will get a better chance in the future.

Case study 5: Return Victim, Age: 28

"If I could know about the pain I have experienced during the journey to Malaysia, I would never dear to go there, I didn't know about these shorts of hassle I have to encounter. They promised me to provide the secured ship with air-condition facilities, television, and regular meals without any delay in service. They further assured us that we would reach the destination to Malaysia very safely and within due time. I could never imagine after such a warm assurance; they could give us such a pain!", Ridwan (25), one of the victims of human 
trafficking, very emotionally gave the above statement when I asked whether he knew about the human trafficking. After returning from Malaysia, he is still bearing the accident's memory during the construction works in Malaysia. He went to Malaysia by a chain of brokers of teknaf. He used to work in the coastal area of teknaf in the southern border area of Bangladesh.

He first heard the job opportunities in Malaysia through his friend. One of the friends of Ridwan proposed a job in Malaysia during the last year. He had to bear one lakh seventy thousand BDT for the procedure cost of migration. However, in reality, they demanded the two-lakh taka. His family managed the money by borrowing loan from the Mahajon of the village. During the journey to Malaysia, he passed 17 days at the Bay of Bengal in an inhuman condition. Initially, there were 6 passengers in the boat. In the Bay of Bengal's international water, they moved to a ship contained around 1,600 passengers from the various parts of Bangladesh, and there were also 6 Rohingya female passengers in the ship. During these days in the ship the broker-come guard regularly beat them up when they demand any food. They only got a one-time meal in a day. Due to the ship's lack of water, their fellow passengers drank their urine during Malaysia's journey. After passing 16 days, they reached in Thailand's coast and stayed additional 17 days in Thailand's jungle. From the border area of MyanmarThailand, the brokers picked them up with a black car and after two days of the journey in the bus he reached in the border of Malaysia. After that, the brokers from Malaysia received him and appointed him at the construction site under one Bengali man's broker on a Chinese farm. After working around 58 days without unpaid in an exploited situation, he got injured while working in the construction of a building. He passed the next 10 days in the hospital, but any of the bosses from his construction site didn't come to the hospital. Finally, the hospital authority called the police and they arrested him and he was punished for the next six months. During that time his poor family in Bangladesh passed a very difficult time in search of him. He called to the number of one of his relatives in the village and requested them to send money to bring him Bangladesh at any cost. At last, his mother begs the money from the door to the door for her son's return from Malaysia. She collected the money from the locals for the safe return of her son. During my field work, he informed me that he is unable to do heavy work above the five $\mathrm{kg}$ because of the accident. He is very frustrated and uncertain about the future because of the local's three and a half lakh loan. His family has left nothing except a broken bamboo made a house for his extended family. His age-old mother is the earning member of the family. He has felt regret for his mother, sister, and wife's unbearable suffering due to his journey to Malaysia. According to the victim, the Bangladeshi illegal migrants are leaving Malaysia to Singapore, Indonesia and Australia. During the conversation with his sister, she said that "we cost much more money for my brother and estimated daily mobile cost for my brother was BDT 1000-1500". I asked one question whether he informs his family about the journey to Malaysia. He replied that he went to Malaysia without informing his mother. His mother argued that "due to my child I have become mad". Does he support anyone to go to Malaysia by illegal means? When I asked the question, he replied that he would never suggest anyone to choose this dangerous and risky path to go Malaysia for the livelihood.

\section{Discussion}

Respondents shared the presence of various causes and theoretical linkage with migration. The Network has a spillover impact over irregular migration. Badshah Mia (65) father of the trafficked vic- 
tim said that the young generation is the main target of the trafficking networks. On the other hand, one of the women of the same village informed that the available information is the premier factor in the decision making of her husband's migration to Malaysia. However, the Ridwan (25) story one of the returned-migrants of the Janglakhata of the Chakaria upzila of Cox's Bazar can be similar with the personal network approach of Boyd \& Nowak (2012) before going to Malaysia. Osman Gani's Story (22) is related to Samers (2010) argument on issues of social and business networks in recruiting cheap labour from the third world countries like Bangladesh through deception. Saskia Sassen (1988) argues that the developed countries' global cities help amplify the migrations' flow from the third world countries for their economic growth. Hence, the five cases mentioned above have been influenced by the trafficking networks that maintain the link with industry. M. J. Piore (1979) argues that developed and industrialist countries follow the dual approaches of the rapid growth in industrial sectors by encouraging the illegal migration. The majority of the respondents answered that their decisionsmaking is highly similar to the arguments of the world system theory (Wallerstein, 1974).

\section{CONCLUSION}

The recent trend of irregular migration in Bangladesh has accumulated in a number of concerns for the policymakers because thousands of young and enable working forces of Bangladesh are trying to migrant abord. Moreover, as the world's largest stateless community, Rohingyas are also vulnerable groups targeted by the traffickers (Khanna, 2020). The Bay of Bengal and the Andaman Sea has become the main route for reaching Malaysia. After analysing the case studies and fieldwork in Ukia, Chakaria of Cox's Bazar and Rangamati district of Bangla- desh, the multi-dimensional causes of the human trafficking were addressed. The trafficking networks easily target these people who have no idea of the migration process. After failing to get a working visa in major migrants receiving countries, they decided to go to Malaysia through the Bay of Bengal's risky path. The core problem of human trafficking from Bangladesh to Malaysia through the Bay of Bengal's maritime route lies in the ineffectiveness and fragile economic policies of the GOB.

At present, 1.1 million, (Roy Chowdhury, 2020) Rohingyas are living in Bangladesh called the world's largest stateless community (Khanna, 2020). They also targeted by the trafficking network. Nonetheless, the other involving regional actors cannot deny their responsibilities in this regard. This study has drawn a number of recommendations. First of all, the Government of Bangladesh has to implement the recent human trafficking-related law of 2012 and 2013 to confront the human trafficking menace immediately. Second, Bangladesh's government must prioritise opening the new labor market, including the Middle East and other prospective areas. Thirdly, regional cooperation must be upheld to control the movement of the people. Bali Declaration on People Smuggling, Trafficking in Persons-2016 is one of the regional instruments to curb irregular migration movement. The implementation of this declaration is a must. Fourth, migration education and the process of safe migration should be included in the awareness campaign targeting the key spots. Finally, the Bangladesh government should keep vigilance to the Rohingya refugees' movement so that they can't become the target of the traffickers.

\section{ACKNOWLEDGEMENT}

I would like to thank my colleagues in the Department of International Relations, Faculty of Social Sciences, Universi- 
Available Online at https://journal.unismuh.ac.id/index.php/otoritas

Otoritas : Jurnal Ilmu Pemerintahan, 10 (2), October 2020, 130

ty of Chittagong for their support and discussions during the research and article writing process.

\section{REFERENCES}

Aronowitz, A. A. (2003), “Coalitions Against Trafficking in Human Beings in the Philippines," United Nations Office on Drugs and Crime and the United Nations Interregional Crime and Justice Research Institute, Vienna, Austria. Available at: http://www.unodc.org/ pdf/crime/human_trafficking/ coalitions_trafficking.pdf. Accessed 4 January 2019.

Aronowitz, A. A. (2009). Human Trafficking, and Human Misery: The global trade in human begins. Westport: Praeger Publishers.

Azad, A. (2019). Recruitment of migrant Workers in Bangladesh: elements of human trafficking for labor exploitation. Journal of human trafficking, 5(2), 130-150.

Bacon, D. (2008). Illegal people: How Globalization Creates Migration and Criminalises Immigrants. Boston: Beacon Press.

Betz, D. (2009). Human Trafficking in Southeast Asia: Causes and Policy Implication. Master's Thesis, Naval Postgraduate School, California.

Bohl, K. (2010). Human trafficking as a livelihood strategy? - A case study of trafficking in women and children from Nepal to India. Master's Thesis, Aolbrong University, Denmark.

Boyd, M., \& Nowak, J. (2012). Social Networks and International Migration, in Martiniello, M., \& Rath, J. (eds.). An Introduction to International Migration Studies. Amster- dam: Amsterdam University Press.

Chowdhury, A. R. (2020). An 'un-imagined community': the entangled genealogy of an exclusivist nationalism in Myanmar and the Rohingya refugee crisis. Social Identities, 26(5).

Khanna, T. (2020) Addressing COVID-ified maritime migration in the Bay of Bengal: the case of stateless Rohingya boat people. Australian Journal of Maritime \& Ocean Affairs, 12 (3).

Hasan, M. (2019). Bangladeshi 'Boat People': Context, Drivers and Policy Implications. South Asia Research, 39(1).

Hossain, M. I. (2020). Impacts of social remittances on economic activities: labour migration from a village of Bangladesh to Malaysia. Migration and Development, 118.

Heckathorn, D. D. (1997). Respondentdriven sampling: a new approach to the study of hidden populations. Social problems, 44(2).

ICDDR, B. (2001). "Trafficking of women and children in Bangladesh, an overview," Special publication no111. Retrieved from: https:// childhub.org/en/system/tdf/ library/attachments/ trafficking_of_women_oct07.pdf? file $=1 \&$ type $=$ node $\& i d=17948$. Accessed on February 23, 2020.

Koser, K. (2007). International Migration: $A$ very Short Introduction. New York: OUP.

Mahdavi, P. (2011). Gridlock: labor, migration, and human trafficking in Du- 
Available Online at https://journal.unismuh.ac.id/index.php/otoritas

Otoritas : Jurnal Ilmu Pemerintahan, 10 (2), October 2020, 131

bai. California: Stanford University Press.

Moretti, S. (2020). Between refugee protection and migration management: the quest for coordination between UNHCR and IOM in the Asia-Pacific region. Third World Quarterly, 1-18.

Muniandy, P., \& Bonatti, V. (2014). Are migrants agents or instruments of development? The case of 'temporary'migration in Malaysia. Journal of Ethnic and Migration Studies, 40(11).

Piore, M. J. (1979). Birds of Passage: Migrant Labour and Industrial Societies. New York: Cambridge University Press.

Rashid, S. R., \& Ashraf, ASM. A. (2016). Asian Boat People and the Challenges of Migration Governance: A Source Country Perspective | Middle East Institute. https:// www.mei.edu/publications/asian -boat-people-and-challengesmigration-governance-sourcecountry-perspective

Ruhi, R. A. (2003). Human Trafficking in Bangladesh: An Overview. Asian Affairs, 25(4), 45-56.
Samers, M. (2010). Migration. London: Routledge.

Sassen, S. (1988). The Mobility of Labor and Capital. New York: Cambridge University Press.

Siddiqui, T. (2014). Irregular Bangladeshi Migrants: where is the Migration Law 2013?. The Daily Star, December 2, 2014, Dhaka.

Siddiqui, T. (2003). Migration as a livelihood strategy of the poor: the Bangladesh case. www.livelihoods.org Accessed on July 27, 2020.

Ullah, A. K. M. A. (2013). Theoretical rhetoric about migration networks: A case of a journey of Bangladeshi workers to Malaysia. International Migration, 51(3).

U.S. Department of State (2020). "Trafficking in Persons Report 2020," Washington, D.C. Retrieved from: https://www.state.gov/ trafficking-in-persons-report2020/

Wallerstein, I. (1974). The Modern WorldSystem: Capitalist Agriculture and the Origins of the European WorldEconomy in the Sixteenth Century. New York: Academic Press. 